\title{
STATE OF THE ART ANALYSIS AND PROFESSIONAL NEEDS IDENTIFICATION IN VOCATIONAL TRAINING DESIGN FOR EURASIAN PRISON CHAPLAINS
}

\author{
Jans Ivans Ignatssons \\ University of Latvia, Latvia \\ Indra Odina \\ University of Latvia, Latvia
}

\begin{abstract}
Prison chaplaincy in the context of whole penitentiary system has been under continuous change with its ups and downs, criticized and appraised by historians, rejected by secular society, yet appreciated by prisoners, and open for judgment of generations to come. The image of the prison chaplain, who is highly educated, not young, skilled in psychological mastery calls far beyond his pastoral functions for a perfect advocate's portrait, which is, however, still under reconstruction.

The article aims to identify what state of the art of Eurasian prison chaplains is to outline the needs of prison chaplains for the framework development of an e-learning platform that would serve as a prototype of vocational training design. An action research was based on Objective-Oriented Project Planning and Logical Framework Approach concepts and studied the participants from six regions in Eurasia with help of such data collection methods as interviews, diary notes and document analysis. The data of action research formed an accurate civilian and professional profile of a prison chaplain and outlined the requirements to maintain the work in line with the trends in the branch. Findings of the research serve as a ground for organizational, educational, professional and personal changes. Eurasian prison chaplains (national directors) express their professional interests in regular training, professional and career growth, improved job practices and better work environment as they can still be an outstanding example and catalyst of well-being in the life of ex-prisoners.
\end{abstract}

Keywords: chaplaincy, well-being, Good News Jail and Prison Ministry, Logical Framework Approach, Objective-Oriented Project Planning, state of the art analysis. 


\section{Introduction}

The global society has experienced significant changes in educational service provision, a wave like tsunami striking hard many governmental institutions and raising upon the surface numerous non-governmental organizations (NGOs) proclaiming a new era since the Global Goals for Sustainable Development were once adopted by world leaders at historic United Nations Summit in September 2015. In 2015 the United Nations established a new concept, and issued 17 goals for sustainable development on how to conquer the hunger, poverty, economic and social inequality, it opened new doors all over the world as a new start in the battle for democracy and humanity. The fact that different nations accept new challenges at such a various pace shows how wide functions and deep in understanding the educator's mission can be. While Latvian Prison Administration establishes a strong, pro-European social model in prison sector other neighbouring countries cannot afford even minimal chaplain service provision, which according to European Prison Rules (2006) means human rights provision for their sentenced citizens.

The context of the research is NGO, known as Good News Jail and Prison Ministry (GNJ \& PM) International, working in Latvia, Lithuania, Russia (Tyumen and Krasnoyarsk Regions), Ukraine and Kyrgyzstan. It provides chaplain services to more than 83000 inmates with a limited staff of 42 mostly part-time working chaplains. At this moment one chaplain is supposed to reach about 1000 inmates on daily basis. However, none of the above-mentioned countries, but Latvia has ratified the Regulations on Chaplain Service yet.

The aim of the article is to identify what state of the art of Eurasian prison chaplains is to outline the needs of prison chaplains for the framework development of an e-learning platform that would serve as a prototype of vocational training design. The following research questions are put forward:

1. What unique qualifications of GNJ\&PM chaplains are?

2. What are prison chaplains' (national directors) personal and professional interests?

3. What specific guidelines in order to develop the framework for vocational training should be considered?

The chosen research method is an action research. The research focuses on leaders of national prison ministries, known as GNJ\&PM Eurasian national directors (further in text national directors) and involves a group of 12 respondents (national director and his deputy if needed), which is the research sample in this case. 


\section{Contemporary understanding of chaplaincy}

Chaplaincy is known since a long time ago. It has shared different names, touched different groups of people, influenced nations in a different pace and level. Chaplains used to be team players and key people in different branches during last 50 years. They used to serve outside the church in such state institutions as prisons, hospitals, army troops and schools. In this research only prison chaplains will be focused on - how the world around and the chaplains themselves see their image in the contemporary setting. Scott (2013 referring to Rev Leslie Lloyd-Rees (1971: 9)) describes a prison chaplain as a "prophet, priest and pastor", where prophets mean bringing "theological insight" into both day-to-day every prisoner's life and "development of penal policy" as such; priests serve as links between God and men; pastors are able to see "people, unique and distinct persons" (Scott, 2013: 49) behind prisoners. Contemporary understanding of chaplaincy has already stepped out of traditional use of the word in terms of prisons; since chaplains are seen in healthcare institutions, schools and even military units all over the world.

Aldridge (2006) points out that some resistance to the professionalization of chaplaincy and challenges for chaplains to fit into secular culture with strive "for excellency and accountability" calls for a strong, "separate and distinctive" profile. Paterson (2015) qualifies the healthcare chaplain as someone, who practises "competency-based learning, attends to the educational, training and personal development needs", "fosters capability and resilience within workforce" and thus forms a portrait of "open and flexible chaplains who operate as spiritual drivers and enablers in health and social care" (Paterson, 2015: 4; Todd, 2013: 146) contributes to a definition of chaplain: non-prison, independent and neutral status, not seen as a part of either prison management, or the regime, which "tend to be the causes of its greatest pains". Scott (2013) stresses the notion of being independent and believes that a key qualification lies in the fact that every chaplain has a calling to prison ministry, and other personal qualities such as sincerity, sensitivity, spirituality and the ability to relate to the prisoners in a nonjudgmental manner.

Todd (2013) outlines chaplaincy as "an alternative domain, within the prison, but perceived as apart from it" and "a safe space" where the chaplain represents someone whom they can speak to and rely upon and a chaplain himself as someone who prevents extremism, radicalization, respects diversity and offers equality of opportunity.

Timmins, Caldeira (2018) outline nine areas where chaplains show their professional, personal and spiritual image which are: 1. hearing confessions, 2. crisis intervention, 3. faith affirmation and ethical consultation, 4. performing a religious ritual and life review, 5. providing a religious item and 
patient advocacy, 6. offering a blessing and counselling, 7. praying and bereavement, 8. meditation and empathetic listening, 9. other spiritual support. Based on the study performed in Great Britain on chaplains and how they reflect on themselves, Sundt (2002) illustrates the chaplains as: 1 . males in $85 \%$, 2. white in $84 \%$ cases, 3. master's degree holders in $60 \%$, bachelor degree holders in $15 \%$ and doctoral degree holders in $18 \%$ cases, 4 . protestants in $70 \%$ cases and Roman Catholics in $26 \%$ cases, 5 . with mean age of 56,5 years. Scott (1996) specifies that prison chaplains shall approach prisoners 1 . with respect, 2 . in order to convince them that the "social self-image", "self-hate" is wrong, 3. in order to combat stigmatizing and dehumanizing consequences of imprisonment, 4 . in order to be a "social bridge" with the "normal world". Sundt, Dammer (2002) point out that 1950s, 1960s brought renewal of chaplaincy with theologically oriented counselling, clinical pastoral counselling, traditional analysis and gestalt therapy. "Chaplains tended to focus either their attention on those few inmates who were interested in religion or they schooled themselves in the late twentieth century's new religion: psychology", state Sundt, Drammer (2002: 63).

Smith (1997) also speaks in favour of holistic model of ministry in prison chaplaincy which exercises positive power, is able to give, support, nurture people, be responsible for others: "It is about partnership and co-operation, about enabling and encouraging others, engaging in nonaggressive confrontation (when the need arises), negotiation and conflict resolution; it is about influencing the process of individual and cultural transformation within the penal system" (Smith, 1997: 252).

To conclude there is a certain tension between the classical view on chaplaincy and constantly changing image of penal system reformers. A chaplain who has always been: alongside powers, of a great importance, a distinctive profile with a set of qualifications, dressed in collar shirt versus a "neutral" person, with rather dimmed character traits, in a continuous transformation process, willing and able to listen to others rather than speak himself, offering others the right for decision rather than being decision-maker over subordinated, someone whose words and intentions are seen in others covered with his pastoral hand. Being self-critical and careful with inmates and patients they still work hard and reach many, despite they are mostly male ministers, they are gentle, may seem to be too simple or too religious or uneducated they carry their doctoral, master and bachelor degrees deep under mantle, being at everybody's disposal.

\section{Methodology and Materials}

To outline the needs of prison chaplains for the framework development of an e-learning platform design that would serve as a means of professional 
development providing online vocational training, the action research has been chosen due to several reasons: first of all, action research is problem centred, client centred, and action oriented; secondly, it involves the client system in a diagnostic, active-learning, problem-finding and problem-solving process; and finally, to be able to design a change and work on changes (designed actions), a special attention ought to be paid on exploring how human beings design their actions in difficult situations and learn new practices.

Contextual and Collaborative Action Research with Interactive/ Collaborative inquiry features where 12 participants - leaders of national prison ministries known as GNJ \& PM Eurasian national directors were invited to design their "future" (further development) - were chosen to identify GNJ\&PM chaplains' professional needs for their own and organizational development. In order to introduce a structured and effective concept of organizational change, Objective-Oriented Project Planning (OOPP) and Logical Frame Approach (LFA) had been applied.

As to Vaccarino, Comrie (2007) contextual and collaborative action research fits larger (working globally) organizations, exploits spirals of steps and circles of planning, actions, results. In present research state of the art analysis of Eurasian prison chaplaincy was conducted to identify their needs for the framework development of an e-learning platform that would serve as a prototype of vocational training design. The case of prison chaplaincy in 6 Eurasia regions requires an interactive inquiry which would balance problem-solving actions and collaborative data analysis in order to enable personal and organizational change.

As there is a tension between personal and organizational interests, there were involved people and they were led to their own personal change, while local ministries had been invited to work for a better organizational improvement. The statement that "knowledge is always gained through action and for action" proposed dynamics and a chain of actions which would settle a continuous change.

Collaborative (or cooperative) inquiry suggests to "research" not "on" people, but "with" people and makes participants active co-researchers where 4 different types of knowledge (propositional, practical, experiential and presentational) are gained (Adelman, 1993). This action research approached organizational development, which could be outlined as "organization improvement through action research". The motivation to change had to be strongly supported with the assumption that if people actively participated in decision-making affecting them, they were more likely to adopt new ways.

Usually LFA serves as a tool for the implementation, monitoring and evaluation of any innovation. Historically LFA was developed in the late 
1960s, adopted as a planning and management tool that proposes eight steps: 1) conduct stakeholders analysis, 2) conduct problem analysis, 3) conduct analysis of objectives, 4) define the intervention logic, 5) specify assumptions and risks, 6) specify indicators, 7) prepare an activity schedule, and 8) specify inputs. This research adopted three first steps of the Log Frame approach with rather detailed analysis of stakeholders (interested parties, with a special focus on 1. chaplains or national directors as the first group - research participants and 2. beneficiaries - inmates in this case). At the first step - stakeholder analysis - the groups, people and institutions were identified which were likely to be affected by the development of online vocational training design, identified the key problems, constraints and opportunities they faced. During the second step - problem analysis problems were formulated, cause and effect relationships were determined, and a paradox table was developed. As to the third step - analysis of objectives - based on the analysis of identified problems, the objectives were put forward and the strategy for Eurasian prison chaplains' vocational training design was determined. The data were collected by interviews with national directors to find out their subjective well-being; the diaries of national directors' self-reflections and document analysis to trace ministry dynamics, evaluate GNJ\&PM chaplains' qualifications, explore their interests, needs, requirements, and predict the desired development.

\section{Results and Discussions}

The action research revealed another side of national directors. At the beginning of the research, national directors showed indifference, disinterest, low level of motivation for any measures undertaken in general and then poor participation in the Strategic Planning Course (Action Phase on the action research) in particular. Semi-structured interviews with national directors revealed conducted their subjective well-being in six dimensions: 1) self-acceptance, 2) personal growth, 3) purpose in life, 4) positive relations with others, 5) environmental mastery, and 6) autonomy (Ryff, 1995). The data reflected most important elements of comfort for personnel as well as success for the whole organization according to which national directors of GNJ\&PM were found satisfied with their life status, jobs and ministry, their family life and personalities/roles, in spite of different background and previous life experience. As majority of chaplains had experienced a tremendous life change once in their past and then continued to work on their character traits, qualities required and appreciated by Christian communities, pro-social behaviours, exemplary lifestyle which would be identified as personal growth process. Their ambitious personal growth was accompanied by interest in their professional development and supported 
by concrete and clear purpose for their life. Their life vision could be summarized by two statements: these people would do what they believed in and would work where they were called to. Their pro-active lifestyle, empathy, giving support and taking care relationships had formed their family model, relationships with relatives, friends and developed the circles of colleagues which became great backup in their life and GNJ\&PM later. The participants were identified as potentially autonomous personalities, however, their cultural consciousness, tight bounds to their Christian communities, political legislation negative towards evangelicals in those countries in general and towards prison chaplains made the participants from eastern parts of Eurasia feel uncomfortable talking about autonomy. Despite restraint autonomy, national directors demonstrated outstanding skills to master their environment in several ways. They had successfully changed their environment in a certain point of their past, which resulted in their choice to work with people for common future well-being. Due to their different and yet unique leadership styles, sometimes negative or even criminal life experience in the past, however, current strong pro-social life orientation, in spite of government limitations and public religious preferences, the national directors fit their local organizations, presented best staff available to lead local chaplain teams, and demonstrated high level of environment mastery.

Thus, the following can be concluded: 1. While GNJ\&PM chaplains have quite high requirements to be people of proven character, convinced in what they do and who they are, there are not many merits in the International Chaplain's Resource Kit which can describe the minimal competence required to apply for a ministry of chaplain / national director, 2. One of the researchers (Area Director, GNJ\&PM Eurasia) has faced a variety of problems dealing with the incompetence of the personnel on the national directorship level, which can be the case in other areas for GNJ\&PM International operating globally as well, 3. The situation where both chaplains and national directors meet with excellence the qualifications for proven character and conviction to be unique on the whole globe and have so many deficits in their managerial skills should be balanced with a "proper training" in sense that those missing skills, which never had been mentioned, trained, treated as important should be invested in by the organization, 4. "Full time ministry" announced in the qualifications above should be changed to "part time" or at least on National Director level the ministers should be motivated/supported/trained to get support for "full time ministry". All local GNJ\&PM chaplain ministries, but Latvia, has got part-time working chaplains, and all national directors (inclusive Latvia) are part-time working staff, which does not support competence gaining/ development concept. 
Based on the data of the diaries of national directors' self-reflections and analysis of documents: monthly reports to identify the dynamics of the ministry and International Chaplain's Resource Kit requirement analysis to compare to the current chaplains' state, the Paradox Table was designed in the form of structured cause-effect hierarchical order current problem situation, and which is the opposite side to the desired future situation (see Table 1).

Table 1. Paradox Table (Ignatssons, 2020)

\begin{tabular}{|c|c|}
\hline Paradox 1 & GNJ\&PM chaplains needs vs offered teaching seminars \\
\hline $\begin{array}{l}\text { Traditional } \\
\text { "teaching } \\
\text { seminars" concept } \\
\text { is too expensive } \\
\text { and too clumsy. }\end{array}$ & $\begin{array}{l}\text { According to GNJ\&PM vision chaplains should be trained } \\
\text { regularly; However, to provide regular training (face-to-face } \\
\text { traditionally, all "students" sitting and listening and "teacher" } \\
\text { speaking - "teacher-centred learning" classroom) requires } \\
\text { high costs with very moderate learning outcomes and that is } \\
\text { why it is never done in sufficient quantity. }\end{array}$ \\
\hline Paradox 2 & Ministry expansion rate vs learning needs satisfaction \\
\hline $\begin{array}{l}\text { Expansion rate } \\
\text { takes } 1.25 \text { times } \\
\text { more seminars } \\
\text { every year. }\end{array}$ & $\begin{array}{l}\text { At the current ministry expansion rate ( } 25 \text { countries/ } \\
20 \text { years) GNJ\&PM reaches } 1.25 \text { country a year, which means } \\
\text { GNJ\&PM must additionally provide at least } 1 \text { extra teaching } \\
\text { seminar per year. It will overload the organization's capacity } \\
\text { at this moment (if GNJ\&PM does it only in a traditional way). } \\
\text { Then not to forget others, which is at least } 1 \text { teaching seminar } \\
\text { every } 2 \text { years, which is } 25 / 2=12 \text { or a little bit more than } \\
1 \text { teaching seminar every month plus } 0.25 \text { extra seminar for } \\
\text { the new country. So, growing needs in education put forward } \\
\text { a question how it can be accomplished. }\end{array}$ \\
\hline Paradox 3 & $\begin{array}{l}\text { Current communication form vs the needs of the growing } \\
\text { ministry }\end{array}$ \\
\hline $\begin{array}{l}\text { The current } \\
\text { communication } \\
\text { strategy does not } \\
\text { meet the needs } \\
\text { of the growing } \\
\text { ministry. }\end{array}$ & $\begin{array}{l}\text { The means of communication are email, WhatsApp, zoom. } \\
\text { More than ever, however, it is still insufficient. Connections } \\
\text { between countries and units are too loose. To support daily } \\
\text { ongoing routines, the ministry should exploit possibly } \\
\text { new way of thinking about communication not only } \\
\text { communication tools. }\end{array}$ \\
\hline Paradox 4 & $\begin{array}{l}\text { Nationally oriented local ministries vs globalization } \\
\text { processes }\end{array}$ \\
\hline $\begin{array}{l}\text { Local } \\
\text { organizations } \\
\text { need to adapt } \\
\text { to globalization } \\
\text { processes and } \\
\text { train the skills } \\
\text { the global society } \\
\text { requires today. }\end{array}$ & $\begin{array}{l}\text { IT/ ICT, globalization processes require the staff to work } \\
\text { effectively and obtain other skills. It differs a lot from } \\
\text { country to country. However, the basic set of the skills to } \\
\text { be developed and improved can remain the same. To create } \\
\text { a qualification development process for higher ranked staff, } \\
\text { different skills and training activities should be focused on. } \\
\text { Many national directors need to improve their communication } \\
\text { skills while many chaplains need a very basic social skill } \\
\text { training. It means that a whole range of skills should be } \\
\text { identified. }\end{array}$ \\
\hline
\end{tabular}




\begin{tabular}{|c|c|}
\hline Paradox 5 & $\begin{array}{l}\text { Two-day teaching seminars vs lifelong professional } \\
\text { training concept }\end{array}$ \\
\hline $\begin{array}{l}\text { Two-days teaching } \\
\text { seminars do not } \\
\text { serve the need } \\
\text { of continuous, } \\
\text { lifelong learning } \\
\text { experience. }\end{array}$ & $\begin{array}{l}\text { GNJ\&PM owns a unique Resource Kit for Chaplain Training. } \\
\text { The problem the chaplains face is that they have just two days } \\
\text { to go through it during teaching seminars or conferences in } \\
\text { one of the countries. They rush through the book and lay it } \\
\text { aside for a couple of years. The ambition is to make GNJ\&PM } \\
\text { Resource Kit a living manual instead of rushing through it in } \\
\text { two days. }\end{array}$ \\
\hline Paradox 6 & $\begin{array}{l}\text { ITC innovations and opportunities to initiate systematic } \\
\text { training vs old expensive face to face training }\end{array}$ \\
\hline $\begin{array}{l}\text { Not using video } \\
\text { and/ or other } \\
\text { ICT innovations } \\
\text { hinders } \\
\text { the organization } \\
\text { to enter } \\
\text { "systematic } \\
\text { training" concept. }\end{array}$ & $\begin{array}{l}\text { The organization has not worked on video recording of its } \\
\text { seminars so far which is a problem for the introduction of } \\
\text { systematic training in the field of prison staff training. } \\
\text { IT/ ICT technologies provide a good base for creating and } \\
\text { maintaining visual tools and IT-based sources for educational } \\
\text { purposes. Face to face training is expensive and ineffective. }\end{array}$ \\
\hline Paradox 7 & Best training manual vs local cultures and traditions \\
\hline $\begin{array}{l}\text { The Resource Kit } \\
\text { is not adapted } \\
\text { by national } \\
\text { organizations to } \\
\text { fit local cultures } \\
\text { and serve local } \\
\text { vision progress. }\end{array}$ & $\begin{array}{l}\text { GNJ\&PM Eurasia experiences a continuous need in equipping } \\
\text { its staff and giving an appropriate training in rapidly } \\
\text { changing environment. The Resource Kit should not only be } \\
\text { presented, but also adapted to local cultural situations. Any } \\
\text { organization with the staff about } 200-300 \text { internationally } \\
\text { and } 200 \text { nationally would face severe difficulties in its } \\
\text { organizational growth unless it solves problems connected to } \\
\text { education and administration. }\end{array}$ \\
\hline Paradox 8 & $\begin{array}{l}\text { The needs of development vs limited old fashioned verbal } \\
\text { PPPs }\end{array}$ \\
\hline $\begin{array}{l}\text { The reports on } \\
\text { educational events } \\
\text { of GNJ\&PM are } \\
\text { mostly presented } \\
\text { verbally, partly } \\
\text { documented. } \\
\text { Further } \\
\text { development } \\
\text { is restricted to } \\
\text { the way how main } \\
\text { departments are } \\
\text { organized. }\end{array}$ & $\begin{array}{l}\text { Today GNJ\&PM Eurasia has got no systematically } \\
\text { documented history on educational and other events. So, it is } \\
\text { difficult to trace each country and their learning and learners' } \\
\text { needs, not speaking about curriculum, syllabus, competences. } \\
\text { The idea of creating a bank of knowledge, a history track - } \\
\text { an archive of development is not new but requires a proper } \\
\text { IT equipment and strategy. All courses, seminars, conferences } \\
\text { can be documented, filed and available to those who join } \\
\text { the organization later and need to get a basic course. } \\
\text { The costs to save and keep video files do not require serious } \\
\text { financial investments. } \\
\text { So, launching the training and education system would give } \\
\text { a start to keep records, organize video and all other materials, } \\
\text { and analyse progress. }\end{array}$ \\
\hline
\end{tabular}




\begin{tabular}{|c|c|}
\hline Paradox 9 & $\begin{array}{l}\text { Different roles and levels of responsibility vs universal, } \\
\text { united knowledge }\end{array}$ \\
\hline $\begin{array}{l}\text { Different levels } \\
\text { of administration } \\
\text { and management } \\
\text { call for various } \\
\text { skills and } \\
\text { differentiated } \\
\text { knowledge. }\end{array}$ & $\begin{array}{l}\text { The idea of growth and expansion means increase of staff } \\
\text { with different levels of knowledge and a broad variety of } \\
\text { skills. How to systematize and structure these "newcomers"? } \\
\text { The current structure of GNJ\&PM International counts with } \\
1 \text { Vice President - } 4 \text { Area Directors - } 25 \text { National Directors - } \\
200 \text { Chaplains internationally. Normally every chaplain has } \\
\text { got volunteers, a Chaplain Board, sponsors and so on. All } \\
\text { these people should have a right to internal education and } \\
\text { training. So, there are } 4 \text { rather big groups which demand } \\
\text { different knowledge and various training of skills. }\end{array}$ \\
\hline Paradox 10 & $\begin{array}{l}\text { Needs for collaboration within the organization and with } \\
\text { outside standing potential partners vs "uniqueness of } \\
\text { GNJ\&PM" image }\end{array}$ \\
\hline $\begin{array}{l}\text { The gap between } \\
\text { requirements for } \\
\text { collaboration for } \\
\text { national chaplain } \\
\text { teams within } \\
\text { the organization } \\
\text { and their real } \\
\text { cooperation } \\
\text { skills is deep. } \\
\text { At the same } \\
\text { time needs for } \\
\text { cooperation } \\
\text { between external } \\
\text { NGOs, educational } \\
\text { bodies and } \\
\text { national ministries } \\
\text { could not be } \\
\text { ignored. }\end{array}$ & $\begin{array}{l}\text { The organization stands quite at its starting point in its } \\
\text { collaboration with other NGOs working in the field. Those } \\
\text { few signals the leadership has received from other similar } \\
\text { international movements remind them they have to include } \\
\text { cooperation possibilities and even promote the competences } \\
\text { which favour collaboration and cooperation. Those } \\
\text { strategies exploit not only multicultural competence, but } \\
\text { also innovations available with IT/ ICT. Collaboration skills } \\
\text { should be developed and knowledge about global sustainable } \\
\text { development in education should be spread. It is impossible } \\
\text { with only traditional teacher-centred classroom method. On } \\
\text { the other hand, such virtual learning platforms as Moodle, } \\
\text { Google Classroom and Office Teams facilitate groupwork } \\
\text { skills and WEB-based learning at the very beginner level. All } \\
\text { "digital aliens" should become "digital natives". }\end{array}$ \\
\hline
\end{tabular}

\section{Conclusions}

The action research had been conducted and the data had been collected and interpreted in order to explore state of the art in Eurasian GNJ\&PM through the analysis of their personal and professional profile, interests as national directors of GNJ\&PM, requirements to do the work of the ministry, and problems they faced in their everyday life.

In-depths analysis of interviews, diary notes and documents indicated that the national directors were exhausted, unmotivated, limited with their primary job tasks; some of them were overloaded in their ministries, some others had already lost their grip on the situation; and all of them were restricted in working time for GNJ\&PM. Half of the respondents who were interested in changes brought forward multiple professional interests. 
Their interests called the GNJ\&PM International for provision of regular training (required skills) and new skills with improved job prospects, where the national directors (and chaplains) would be aware of their career growth. The national directors indicated their interest in improved work practices and creation of motivating work environment.

National directors expressed interest in their involvement in new curricula development and new work practices depending on their competence and engagement level.

In case of successful implementation of the above listed requirements and taking care of the staff's well-being and interests, the national directors would adopt new roles and perform new functions. The research cleared up that the national directors would update their teams of chaplains/ other interested parties on the ministry progress, participate in training design. This would practically mean to increase the national directors' online and offline work time in order to evaluate GNJ\&PM progress, analyse chaplains' learning and general needs, define necessary skill training, engage with teams, volunteers, potential partners.

Skills and competences needed to form vocational training design are those primary "know-how" qualities:

1. ability to transform a curriculum into a modular system;

2. ability to handle different target groups;

3. ability to respond to innovations;

4. passion and perseverance;

5. creativity and not being afraid of failures;

6. life skills.

What makes vocational training a very special art is a set of the following requirements: there is a big gap between school and vocational school, formal education and vocational education. Chaplains can be classified as professionals who match their professional standards, which require vocational education in its turn. In European countries it varies from country to country, however, can demand the completion of 2 years professional school organized as an e-learning platform. Besides, up to $70 \%$ of time should be devoted to the development of specific skills and $30 \%$ of training time to the theoretical knowledge.

Both trainers and trainees need to know the labour market, the conjuncture, state policies and requirements in formal educational institutions. Chaplaincy in Eastern Europe can cause an irritation in traditional correctional system, however, it is the only way to provide better services and democracy-based thinking into conservative bureaucratic societies where informal and non-formal education has not shown its full effect yet.

So, to summarize it all the following should be stated: vocational training design should be given a special attention, time and care. It is a challenge 
to formal educational systems, governments promoting punitive measures and preferring correctional policies normally found in those countries where non-formal, informal education providers, often presented by NGOs cause mistrust and even hatred and dissatisfaction.

\section{References}

Adelman, C. (1993). Kurt Lewin and the Origins of Action Research, Educational Action Research, [online]. Available at: http://www.tandfonline.com/doi/abs/ 10.1080/0965079930010102 [Accessed 16 September 2019].

Aldridge, A. (2006). The Unique Role of a Chaplain, Scottish Journal of Healthcare Chaplaincy, [online]. Available at: https://www.academia.edu/3425946/The_unique_ role_of_a_chaplain [Accessed 16 September 2019].

Ignatssons, J. I. (2020). State of the Art Analysis to Define Professional Needs of Eurasian Prison Chaplains. Master's Paper. Riga: University of Latvia.

Paterson, M. (2015). When the Chaplain Is Ready the Teacher Will Appear, Health and Social Care Chaplaincy, [online]. Available at: https://www.researchgate.net/ publication/279279629_When_the_Chaplain_is_Ready_the_Teacher_will_Appear [Accessed 19 October 2019].

Ryff, C. (1995). Psychological Well-Being in Adult Life. Current Directions in Psychological Science, 4(4), 99-103. Available: http://www.jstor.org/stable/20182342?seq= 2\#page_scan_tab_contents.

Scott, D. (2013). Priests, Prophets and Pastors: The Historical Role of the Prison Chaplain, Justice Reflections. [online]. Available at: https://www.academia.edu/11405930/Priests_ prophets_and_pastors_the_historical_role_of_the_prison_chaplain [Accessed 15 September 2019].

Smith, H. (1997). Chaplaincy, Power and Prophecy in the Scottish Prison System: The Changing Role of the Prison Chaplain. [e-book] Edinburgh: The University of Edinburgh. Available at: https://www.era.lib.ed.ac.uk/handle/1842/30771 [Accessed 9 September 2019].

Sundt, J. (2002). The Correctional Ideology of Prison Chaplains: A National Survey, Journal of Criminal Justice, [online]. Available at: https://www.researchgate.net/ publication/223712648_The_correctional_ideology_of_prison_chaplains_A_national_ survey[Accessed 11 September 2019].

Sundt, J., Dammer, H., Cullen, F. (2002). The Role of the Prison Chaplain in Rehabilitation, Journal of Offender Rehabilitation, [online]. Available at: https://www. tandfonline.com/doi/abs/10.1300/J076v35n03_04 [Accessed 9 September 2019].

Timmins, F., Caldeira, S., Murphy, M., Pujo, N., Sheaf, G., Weathers, E., Whelan, J., Flanagan, B. (2018). The Role of the Healthcare Chaplain: A Literature Review, Journal of Health Care Chaplaincy, [online]. Available at: https://www.semanticscholar.org/ paper/The-Role-of-the-Healthcare-Chaplain\%3A-A-Literature-Timmins-Caldeira/ ff7a151d90c713b113581a020af4ec729952def8 [Accessed 9 September 2019].

Todd, A. (2013). Preventing the "Neutral" Chaplain? Practical Theology, [online]. Available at: https://www.tandfonline.com/doi/abs/10.1179/1756073X13Z.0000000006 [Accessed 9 September 2019]. 
Vaccarino, F., Comrie, M., Murray, N., Sligo, F. (2007). Action Research Reflections: The Wanganui Adult Literacy and Employment Project. New Zealand: Massey University. Available at: https://www.massey.ac.nz/massey/fms/Colleges/College\%20 of\%20Business/Communication\%20and\%20Journalism/Literacy/Publications/Action_ Research_Reflections.pdf?A29032502C0118C4A017245B9095FC1A [Accessed 10 July 2020]. 